\title{
Xenophon in a Black Sea Landscape: Settlement Models for the Iron Age on the Sinop Promontory (Turkey)
}

\author{
Owen Doonan \\ California State University, Northridge, USA
}

Research into the Iron Age of Anatolia has seldom paid sufficient attention to settlement patterns and the social organization of space. The Anabasis by Xenophon records the observations of a Greek outsider who travelled across eastern Anatolia and along the Black Sea coast in 400 BCE, a time that was relatively early in the colonial process in this area. Xenophon's observations are used to establish a basic model for settlement in the Black Sea coastal region of Anatolia, which is then tested against the results of recent archaeological surveys and related research on the Sinop promontory. A fuller and richer model of indigenous Iron Age settlement and colonial engagement on the Sinop promontory is developed and considered in light of recent research on colonization in the western Mediterranean and northern Black Sea regions.

Keywords: Anatolian Iron Age, Greek colonization, Black Sea Iron Age, Xenophon, landscape archaeology

\section{INTRODUCTION}

The first half of the first millennium BCE marked a turning point between the divergent Anatolian and Black Sea economies of the Bronze Age (third and second millennia $\mathrm{BCE}$ ) to a deepening integration of Anatolia into the extensive regional economies of northern Eurasia during the Iron Age (first millennium BCE). Historians and archaeologists most frequently emphasize the development of local kingdoms and polities that might be recognized through distinctive material culture, including ceramics and portable luxury goods. Despite widespread acknowledgement of the fallacy of the 'pots = people' equation (Kramer, 1977), there is an almost irresistible urge to attempt to reconstruct the ethnic mapping of Anatolia that arises from the valuable and interesting body of historical sources available for the period (see, for example, the reviews in Genz, 2011 and Tsetskhladze 2012). Phrygians, Cimmerians, Lydians, and Urartians dominate the discussion, their material assemblages defined by excavations at large and impressive centres (Sardis, Gordion, Kerkenes Dağı, Kaman kale, Altıntepe; see Figure 1). Recent systematic surveys have begun to establish basic patterns for occupation in the spaces between the centres (e.g. Central Lydia Archaeological Survey, Project Paphlagonia), but our understanding of Iron Age Anatolian settlement as a spatial phenomenon remains woefully underdeveloped ${ }^{1}$.

1 See papers in Steadman and McMahon (2011) for discussions of the sites listed here, and Doonan, 2013 for an overview of recent systematic survey projects in Anatolia. 


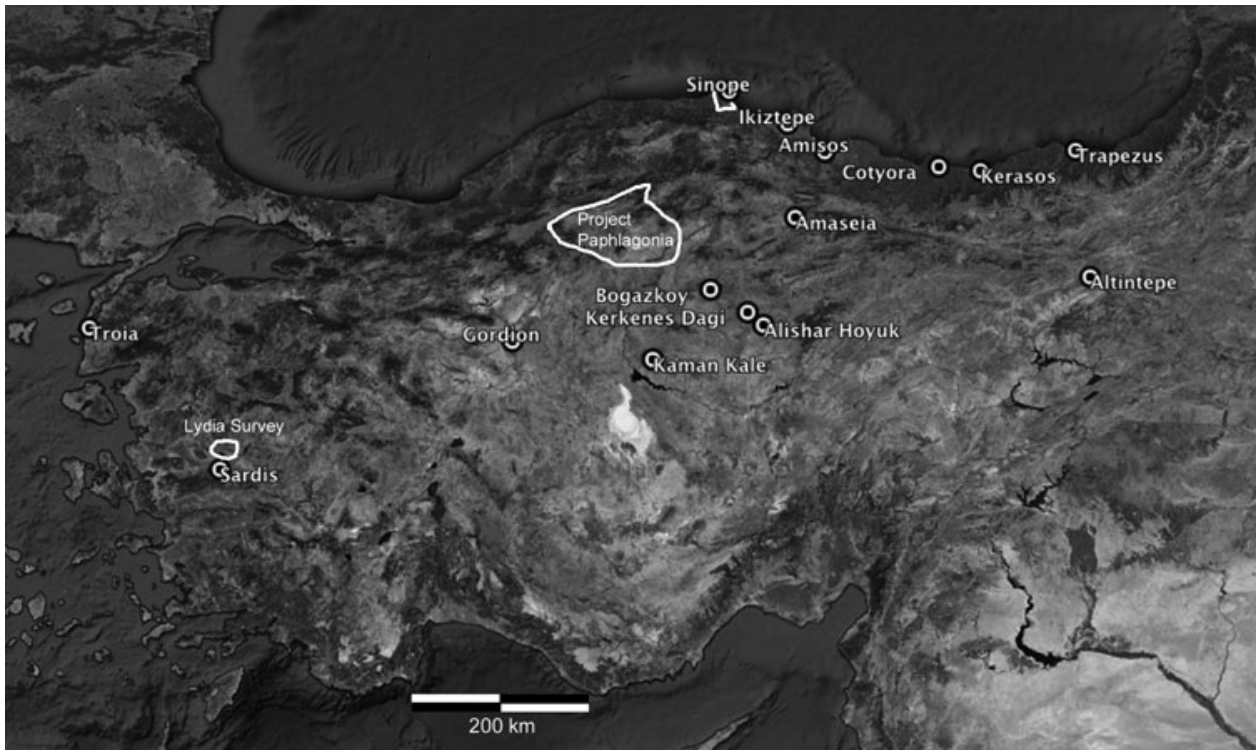

Figure 1. Map of Anatolia indicating the first millennium BCE sites mentioned in the text. The Sinop promontory extends north at the midpoint of the south coast. The tribes mentioned in Xenophon's narrative are clustered near the Ionian colonies of Trebizond, Kerasous and Kotyora.

This article seeks to reorient the investigation of Iron Age settlement in Black Sea Anatolia more towards an understanding of economic and settlement patterns than to ever more precisely defined ceramic (read ethnic) mappings. Although the approach followed here may not be suitable for all parts of Anatolia, it may offer a way out of a conundrum we face on the northern side of the Pontic watershed. An apparent gap in settlement following the Early Bronze Age (more correctly the absence of recognizable late second and early first millennium $\mathrm{BCE}$ ceramic types) contradicts the historical accounts that pertain to this region. Such an approach lays the groundwork for a more synthetic approach that can consider comparisons to better-established case studies in the Mediterranean, the Black Sea, and Anatolia. This has particular relevance to the investigation of contrasting case studies in indigenous-colonial relations.

The early-mid first millennium BCE remains elusive on the Sinop promontory despite a now extensive record of archaeological surveys using both systematic and opportunistic methodologies. The Sinop Regional Archaeological Project (SRAP hereafter) has now conducted a number of systematic surveys in the region through which it has established a sufficient body of data to revisit the question of first millennium BCE indigenous settlement on the promontory (Doonan, 2004a; 2007a; Doonan et al., 2015). It is has been particularly challenging to define and identify the Iron Age on the Sinop promontory $^{2}$ for a number of reasons:

1) Continuation of a handmade undecorated ceramic tradition as late as the late first millennium BCE; conservative undecorated forms with few diagnostic features;

2 This article focuses primarily on the Sinop promontory from the watershed of the Pontic coastal mountains to the sea. Those parts of the Sinop province to the south of the mountains have been described in detail by Dönmez $(2007,2008,2011)$ who also treats some areas under discussion here. 
2) Relatively low site density, probably attributable to the short duration of the Iron Age rather than to a decrease in actual settlement density at any point in time (Iron Age duration of 500 years in comparison to a Bronze Age duration of 2000 years); and

3) Settlements tend not to be readily visible in a systematic survey methodology that emphasizes cleared agricultural fieldsindigenous settlements are compact, tend be uncultivated and overgrown because of a preference for mounded and sloping sites, and have sparse ceramic and lithic material on the surface.

The fundamental challenge in defining the Iron Age on the Sinop promontory lies in the poor understanding we have of indigenous ceramic chronologies. The orthodox position is to assign the undecorated indigenous handmade wares to the Chalcolithic or Early Bronze Age, based in many cases on tenuous formal similarities to wares and forms from Alışar Höyük and other sites from the Anatolian highlands. The most reliable evidence for dating early sites comes from specific and concrete parallels with the assemblages from the important excavations of İkiztepe, $90 \mathrm{~km}$ east of Sinop in the delta of the Kizllirmak river (see, for example, Dönmez, 2004). However, only a limited proportion of the handmade assemblages from the Sinop promontory north of the coastal mountain watershed can be precisely connected to parallels at İkiztepe.

Following on the idea proposed above, rather than approaching the problem of the Iron Age in Sinop as a matter of matching pottery types to ethnonyms, we might consider it a matter of understanding settlement patterns and complex spatial relations between indigenous and intrusive communities in the context of developing relationships. Local communities engaged outside traders dynamically through a spatial and cultural system already in place at the time of early contact (Doonan 2007a, 2007b). In the southern Black Sea region, new evidence from the investigations at Sinop suggests that a system of inland and coastal communities supporting a population of specialist mobile fishermen laid the groundwork for trade relations with outsiders (Doonan et al., 2016; for discussion of fishing evidence in the northern Black Sea region see Gavriljuk, 2005). Textual sources, likewise, might be used in a systematic manner to establish expectations for testable patterns that might be identified through survey rather than the more conventional approach to use them as a guide to ambiguous or even untestable ethnic mappings (see, for example, Lipka, 1995, or Tsetskhladze, 2014).

As a starting point, let us consider the undecorated handmade bowls and holemouthed jars found north of the Sinop watershed, more specifically dating indigenous' wares in association with known assemblages rather than arbitrarily assigning fourth- or third-millennium dates to them. The dating of these assemblages is very tenuous, based on ware types and forms with minimal diagnostic features. Handmade wares, mostly low-fired and coarse, some burnished with forms ranging from shallow bowls to holemouthed jars, are divided into categories based on distant and far-flung excavations. It is clear that some of these really are Early Bronze Age: those types that show close correspondence with Ikiztepe, a halfday's sail down the coast, are certainly interpreted correctly.

An analysis by Alexander Bauer shows more diversity than conformity in local handmade ware types and fabrics, but conformity in forms (Bauer, 2006). In fact, many local 'Early Bronze Age' types look as similar to humble handmade wares used at Iron Age Boğazköy as they do to thirdmillennium antecedents (Genz, 2004: 
51-61, plates I-XXV). There is sufficient historical documentation to suggest that settlements of local tribes were well established along the Pontic coastal region during the first millennium $\mathrm{BCE}$ (e.g. Xenophon, Anabasis, Book V), and so it seems more logical to attribute the anomalous two-millennium gap in settlement to our poor understanding of local ceramic sequences rather than to an actual gap in settlement. The SRAP has undertaken a comprehensive programme to date handmade wares by luminescence and establish technologically-based typologies from a broad group of settlements across the Sinop promontory in order to remedy this problem (Doonan et al., 2008; Casson 2014; Casson et al., 2012; Bauer and Sherratt 2018). This research project is still in its early stages and so the remarks in this article will have to be regarded as preliminary and based on a necessary degree of chronological speculation.

\section{Towards a Model for Iron Age Settlement in Black Sea Anatolia: A Consideration of Contemporary Primary Sources}

Ancient literary sources provide potentially useful contextual information relevant to the interpretation of the evidence from the Sinop promontory. Some later sources, such as the Roman geographer Strabo, a native of the nearby city of Amasia, are considered highly reliable for the Hellenistic and early Roman periods. However, Strabo and other later sources will not be considered here because their observations on indigenous cultures will certainly contain distortions based on the fundamental changes that took place in the region over the fourth-first centuries $\mathrm{BCE}$.

This analysis focuses on the account in Xenophon's Anabasis in developing a model for Pontic settlement north of the coastal mountains during the mid-first millennium BCE. Xenophon, together with a large Greek army, crossed the Pontic mountains behind the Ionian colony of Trebizond and proceeded west along the coast in 400 BCE (Figure 2). His rich observations on the encounter and relationships between Greeks and indigenous communities can be very useful to us as we seek to enrich our understanding of the nature of settlement and community life in the coastal Pontic mountains during the Iron Age. One note of caution should however be struck: Xenophon's descriptions are of encounters in the eastern Black Sea area and so do not precisely correspond to the situation on the Sinop promontory. Nonetheless, the regions from which a detailed account survives are broadly similar to the Sinop promontory in terms of resources, climate, landforms, indigenous economies, and social organization. The human geography of both regions is dominated by steep coastal mountains, deeply incised river valleys with limited navigability, a humid subtropical climate, and loose tribal organization before the emergence of the Pontic Kingdom in the third century BCE. Strabo (2.1.16-17) considered the coast from Sinope to Phanaroea (the delta of the modern Yeşilırmak/ancient Iris river to the east of Samsun/ancient Amisus) to be an ecologically distinctive zone conducive to olive production. This would make it a microclimate uniquely similar to the east coast of the Sinop promontory and it is not unreasonable to suggest that broad similarities in economy, settlement, and social organization might have existed along the coast.

Xenophon's account is valuable in part because the observations he made about local cultures, the economy, and settlement are incidental to his narrative. The suggestion that Xenophon may have kept some kind of diary is consistent with the 


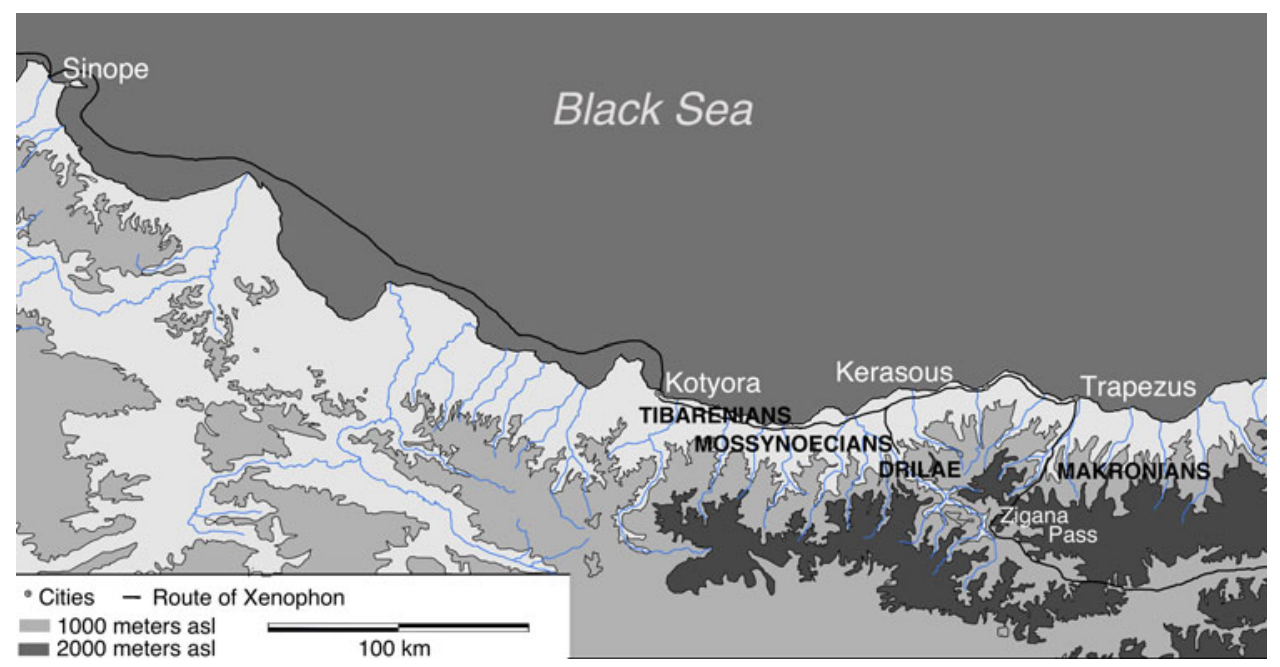

Figure 2. Map of the Anatolian Black Sea region from Sinop to Trapezus (modern Trabzon). Elevations are shaded, Xenophon's approximate route is marked by a black line, and the names of tribes mentioned in the text are written in capital letters.

level of detail in the Anabasis, although this point is difficult to prove (Flower, 2012: 61-63). There is a legitimate debate over the reliability of Xenophon's field observations, for example whether he relied on memory unaided, or on personal notes, or other sources for the details in his account (as Stylianou, 2004 suggests; see Caukwell, 1972 for an alternative view). His observations are not nearly as coloured by a larger agenda as were other fifth-century 'ethnographic' sources like Herodotus (but see Rood, 2014). Xenophon was an Athenian general who led an army of 10,000 mercenaries to Persia to assist Cyrus the Younger seize the throne from his brother Artaxerxes II in $401 \mathrm{BCE}$. The march of the mercenaries from western Anatolia to Persia and their return across eastern Anatolia and along the Black Sea back to Greece is the subject of Xenophon's Anabasis. The army crossed the eastern Black Sea mountains through the Zigana pass behind Trapezus, marched west along the coast as far as Kotyora, and then proceeded by ship to Sinope and beyond (Figure 2).
We may thus consider the possibility of broadly similar patterns in settlement, economy, and cultural relations among indigenous communities along ecologically and topographically similar areas of this coast. On the other hand, there is no reason whatsoever to wade into historical questions such as the naming of tribes and the identification of particular ethnic entities-often a distracting temptation when considering sources such as these. We will consider three themes under the rubric of settlement and economy: settlement form and distribution; social and economic entanglement between coastal and interior and indigenous groups; and economy.

\section{Settlement in the Pontic Mountains}

\section{Metropolis of the Drilae}

'When the Greeks reached the mountains, the Drilae set fire to those of their villages which struck them as being vulnerable to attack, and withdrew. There was nothing for the 
Greeks to take except for the occasional pig or ox, or some other animal that had escaped the flames. One stronghold, however, was their mother city and this was where they had all congregated. There was an extremely deep gully around the place and all the approaches to it were difficult to negotiate. The peltasts, who had run five or six stades ahead of the hoplites, crossed the gully and attacked the place, because they had spotted plenty of livestock, including sheep and goats. Over two thousand men crossed the gully, because the peltasts were joined by large numbers of spearmen, who had come out after provisions. They were unable to take the place by force of arms, however, because a wide trench had been excavated around it, and the embankment made from the excavated earth had been fitted with a palisade and wooden towers set at close intervals.' (Xenophon, Anabasis V.ii.3-6)

The Greeks followed the Drilae along a series of riverine settlements until they found themselves trapped and unable to take a highland stronghold. There appear to have been outlying farmsteads surrounding a citadel surrounded by multiple earthworks. The Greeks entered the citadel believing that they had captured it easily, but were put to flight by a strong force that issued out of a citadel within. It appears that the large settlement included both a citadel and an outer town defended by a rampart and palisades. The large and powerful force extracted itself from the town with great difficulty, and had to distract the Drilae by burning their town in order to enable their own retreat.

\section{Wooden tower of Mossynoecian king}

'However, their king, who was inside the wooden tower built on top of the hill and who was maintained by contributions from the whole population while he was the resident and guard of the tower, refused to leave it, and so did the ruler of the stronghold they had taken earlier. So they were incinerated along with the towers.' (Xenophon, Anabasis V.iv.26)

Highland centres, even those associated with powerful leaders, were constructed of timber and highly susceptible to fire. Recognized leaders ('kings') seem to have been based in the highlands rather than in coastal sites.

\section{Mossynoecian villages}

'Towns were located at intervals of more or less eighty stades, but the layout of the land, with its mountains and valleys, was such that the inhabitants of one town could hear people shouting to them from the next one.' (Xenophon, Anabasis V.iv.30-32)

This passage reinforces the impression that relatively small settlements were distributed along river valleys within earshot of one another. The approximation of 80 stadia (c. $15 \mathrm{~km}$ ) gives a rough idea of the distances between settlements. The observation that settlements were within earshot of one another suggests a more likely distance of $5-8 \mathrm{~km}$ between settlements given the optimal acoustical conditions along the steep Pontic ravines. The discrepancy may be due to the difficulty of estimating distances over the challenging terrain.

\section{Tibarenian coastal villages}

'Next they came to the Tibarenians, whose land was far more flat and whose villages by the sea were less well fortified.' (Xenophon, Anabasis V.v.2)

The Tibarenians lived in settlements with some defensive capabilities just east of the 
Sinopean colony of Kotyora. They settled in coastal plains and relied on hospitality as a strategy to maintain good relations with the Greeks. Although the Greeks first came upon them with hostile intent it is clear that the Tibarenians were skillful at negotiating with outsiders - this may reflect a long tradition of relations between mobile fishing communities from around the Black Sea interacting with local indigenous communities. New findings from Sinop kale suggest a mobile community of maritime specialists engaged in a symbiotic relationship with terrestrial-oriented groups from as early as the third millennium BCE (Doonan et al. 2016).

\section{Integration of highland-coastal economies}

When the Greeks looted the strongholds, they found in the houses piles of stored loaves, which according to the Mossynoecians were made from the previous year's flour, while the fresh grain was stored with the straw. Most of the grain was spelt. There were also jars of dried dolphin meat and pots of dolphin blubber, which the Mossynoecians used for the same purposes that the Greeks use olive oil. The attics of the houses contained a great many flat, unsegmented nuts which, when boiled and baked into loaves, were the Mossynoecians' main food. There was also wine, which tasted sharp when undiluted, because it was so rough, but when diluted it had a pleasant scent and flavour.' (Xenophon, Anabasis V.iv.28)

Communities along the river valleys were not only linked by soundscapes and military strategies. This passage highlights the importance of dolphins as a source of food and fat in the highland diet and illustrates that the Mossynoecians took advantage of a wide variety of resources from different environmental zones: arboreal products from the mountains (chestnuts used as flour for bread), agricultural products from the coastal plain (stores of spelt and wine laid up), and maritime products (dolphin blubber and salted meat). Xenophon describes this diverse array of foods as typical to individual highland households. The overall impression is of interdependent communities that each specialized in exploitation of distinct environmental zones (highland, coastal, maritime).

\section{Discussion}

Table 1 outlines some of the settlement characteristics that may be traced in this documentary settlement record. Overall, the pattern we can discern from Xenophon is one of politically independent, rival indigenous tribes organized from east to west along the river valleys that flow from the high mountains to the coast. Rivalries appear to be fierce, and burning smaller settlements seems to have been a common and effective tactic of war. The inhabitants of coastal settlements may have supplied fish and dolphin products and occasional goods from exchange with the Greeks to their highland kin who maintained political and military strongholds in the mountains. Settlements were inter-visible along river valleys, and close enough for inhabitants to call along the valleys. Towers and/ or signal fires may have facilitated rapid communication along the valleys in times of emergency.

The coastal settlements were clearly the critical points of contact between Ionian traders and indigenous tribes, since such groups were more practised at establishing productive relations with the Greeks. Coastal communities like the Tibarenians were clearly familiar with passing Greeks and had experience of setting up ad hoc 
Table 1. Settlement characteristics for Black Sea Anatolia derived from Xenophon's Anabasis.

\begin{tabular}{|c|c|}
\hline $\begin{array}{l}\text { Settlement } \\
\text { characteristic }\end{array}$ & Proxy evidence \\
\hline $\begin{array}{l}\text { Economic integration } \\
\text { along river valleys }\end{array}$ & $\begin{array}{l}\text { Dispersal of traded } \\
\text { goods from the coast } \\
\text { to the highlands }\end{array}$ \\
\hline $\begin{array}{l}\text { Political centres in the } \\
\text { highlands }\end{array}$ & $\begin{array}{l}\text { Larger, better defended } \\
\text { settlements in the } \\
\text { highlands }\end{array}$ \\
\hline $\begin{array}{l}\text { Agricultural settlements } \\
\text { in coastal plains }\end{array}$ & $\begin{array}{l}\text { Undefended settlements } \\
\text { in coastal plains with } \\
\text { access to agricultural } \\
\text { land }\end{array}$ \\
\hline $\begin{array}{l}\text { Settlements interspersed } \\
\text { along valleys within } \\
\text { earshot }\end{array}$ & $\begin{array}{l}\text { Distribution of discrete } \\
\text { settlements at a dis- } \\
\text { tance of } 5-8 \mathrm{~km} \\
\text { within river valleys }\end{array}$ \\
\hline $\begin{array}{l}\text { Smaller settlements in } \\
\text { the foothills }\end{array}$ & $\begin{array}{l}\text { Prevalence of smaller } \\
\quad(<5 \text { ha }) \text { settlements } \\
\text { in elevations below } \\
800-1000 \mathrm{~m} \text { asl }\end{array}$ \\
\hline $\begin{array}{l}\text { Defensive burning of } \\
\text { settlements }\end{array}$ & $\begin{array}{l}\text { Evidence of burning at } \\
\text { Iron Age settlements }\end{array}$ \\
\hline Wooden architecture & $\begin{array}{l}\text { Scant evidence of alter- } \\
\text { native construction } \\
\text { materials (stone, mud } \\
\text { brick) at settlement } \\
\text { sites }\end{array}$ \\
\hline $\begin{array}{l}\text { Rampart and palisades } \\
\text { surround highland } \\
\text { strongholds }\end{array}$ & $\begin{array}{l}\text { Evidence of terracing } \\
\text { around major highland } \\
\text { settlements }\end{array}$ \\
\hline
\end{tabular}

markets at short notice. The great number of small boats raised by the Mossynoecians at a moment's notice testify to engagement in maritime activities. Given the clear political and military priority of the highland settlements, and the great predictability of Pontic fish migrations, the possibility of seasonal occupation along the coast should be considered. Since maritime products were distributed into the highlands, it would not be surprising to find imported goods at highland sites, although trade does not appear to have become a stable component of the indigenous economy by the time of Xenophon's journey. We now turn to an archaeological case study on the Sinop promontory to consider whether archaeological evidence suggests that the features noted by Xenophon may have been present in a Black Sea coastal environment.

\section{Archaeological evidence from the Sinop promontory: the Kırkgeçit çayı Survey}

The Kurkgeçit çayı survey (Figures 3 and 4) is the second of two three-year systematic archaeological surveys carried out to date by the SRAP. (See Doonan, 2004a and 2004b and Doonan et al., 2001 and 2015 for details of the SRAP survey sampling approach and methodology.) The survey was designed to examine contrasting patterns in two river valleys that ran from the rugged coastal mountains on the Sinop promontory to the coast just north of the secondary port of Gerze. The Kırkgeçit çayı (meaning 'forty-crossings river') has cut a deep, steep-sided valley in the schist bedrock that nonetheless was used as the main crossing over the mountains in the Sinop promontory from Roman times until the present day (Doonan et al., 2015). A few kilometres to the south, the Sarımsaklı çayı has formed a second valley that cuts less directly over the mountains (Doonan and Bauer 2005).

\section{The Kırkgeçit çayı bighlands}

The best-documented example of the highland settlement pattern is in the Tingıroğlu district where several small loci (each $<0.5 \mathrm{ha}$ ) were documented in a cluster around a large (6 ha) central site (Locus L11-32, 33, and 34; Doonan et al., 2015). Most of the diagnostic material from the larger site could be related to the Hellenistic cultural horizon although the smaller sites showed exclusively handmade local wares. It is not clear whether these are contemporaneous, or suggest longer temporal continuity. The mixed ceramic assemblage ranges from coarse handmade wares in black and 


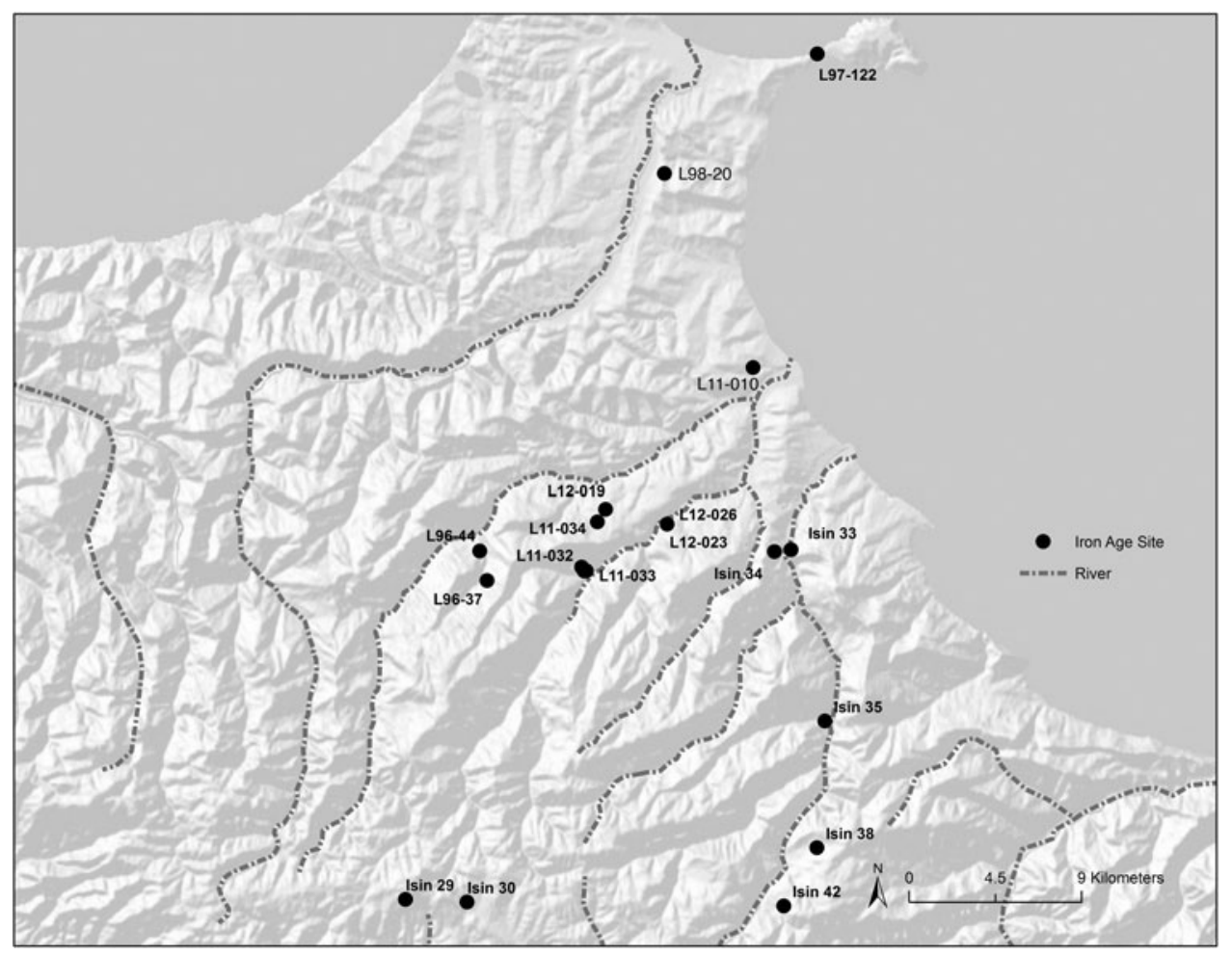

Figure 3. Map of indigenous (probably Iron Age) sites north of the Pontic watershed on the Sinop promontory. Sites named in the text include Sinop kale (L97-122), Karapinar (L98-20), and Kayanin basi (L03-01). The Kirkgeçit çayn system drains into the Black Sea about five km north of the Sarımsakl çayı. Map produced by Matthew Conrad.

reddish-yellow fabrics to amphorae, bowls, pithoi, and roof tiles typical of the latter first millennium BCE. The overall organization is reminiscent of patterns (numbered 6 and 8 in Table 1) from Xenophon's narrative with smaller satellite settlements within earshot built in timber near a larger main settlement.

\section{Tingrtepe}

Another large (6 ha) locus, two $\mathrm{km}$ to the west of the cluster of settlements in Tingıroğlu, was first documented by Işin (1998) and recorded more completely by our team in 1996 and when we revisited the site in 2006 (Doonan et al., 2008). This site (Figures 5-7) included an extensive scatter of handmade wares on the slopes beneath a stone-built tower and associated walls and terraces. The entire surface of the site showed evidence of burning. A stone tower, extensive walling, and burnt occupation deposits were observed in illegal excavations in the citadel area of Tingirtepe. Similar large fortified sites have been noted in the highlands or just south of the watershed of the Black Sea mountains, in Sinop province (Salar, see Doonan, 2004a) or Akalan (Macridy-Bey, 1907; Dönmez \& Ulugergerli, 2010).

Ceramic finds included local handmade wares in a coarse black fabric, closed forms with smoothed exteriors, some carinated forms; the presence of later first-millennium amphora fragments show a colonial connection in the Late Iron Age phase of 


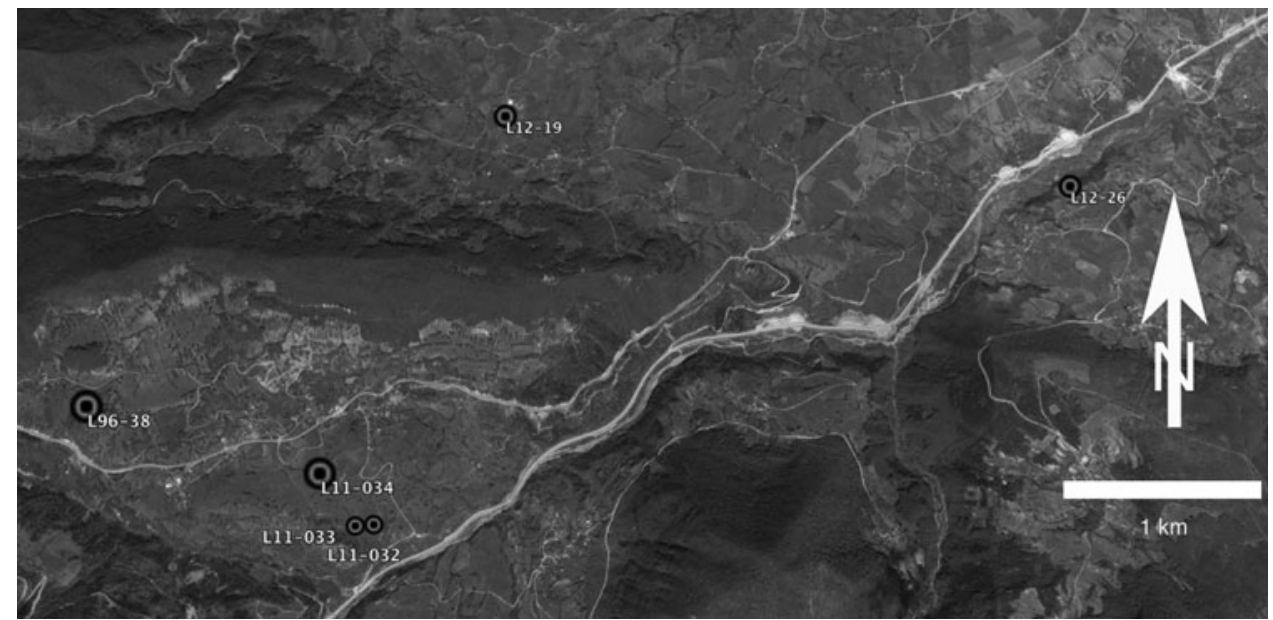

Figure 4. Iron Age loci in the Kirkgecit çayn highland area. L96-38 (Tingirtepe) and L11-034 are more than 6 ha in extent, all the others are smaller than 1 ha. Stone towers and terrace walling were recorded at L11-26 (Yakadibi) and L96-38 (Tingirtepe), both of which showed evidence of burning. The Tingiroglu plain is sheltered by high ridges to the north, south and west and the steep-sided canyon of the Kirkgeçit çayn to the south and east.

the site. Altogether the evidence from the SRAP and other surveys suggests that the Tingıroğlu area was a centre of highland indigenous settlement in what was initially a dispersed settlement pattern; at some point, perhaps around the time of colonial encounters in the mid-first millennium BCE, larger population centres emerged. This was not necessarily to the exclusion of the outlying small settlements that are very hard to date.

\section{The Kirkgeçit çayı foothills}

During the 2011-2012 seasons a string of sites was identified along the Kirkgeçit çayı on terraces overlooking the river (Figure 4). We have already mentioned that the Tingiroğlu sites show plentiful settlement in the areas controlling access to the highland passes. The foothills also show a pattern of settlements straddling both sides of the valley: in Erikli, village sites are distributed along the top of the ridge overlooking the north bank of the river; a settlement exists at Yakadibi above the south bank of the river, and then further sites are located in the coastal plains. Many of these sites are adjacent to or near Hellenistic-period occupations, but assemblages are seldom mixed. Our working hypothesis is that the Iron Age sites are earlier, and that the Hellenistic material represents the economic and cultural engagement of these indigenous communities with colonists from the fourth century BCE onward.

The Yakadibi site (L12-26) is located some $50 \mathrm{~m}$ above the river-bed, relatively close to the river itself. A stone tower sits adjacent to a massive burnt lime deposit with a terrace occupied below. This appears to be a very strategic location, visible to the Tingıroğlu sites and similar in overall plan to Tingirtepe but with a commanding view of the outlet of the valley. The site's proximity to the river may imply a crossing nearby. A fragment of a high-footed bowl was found embedded in the rock-hard burnt lime deposit. The bowl is a low-fired, coarse red ware with smoothed surface, tempered with 


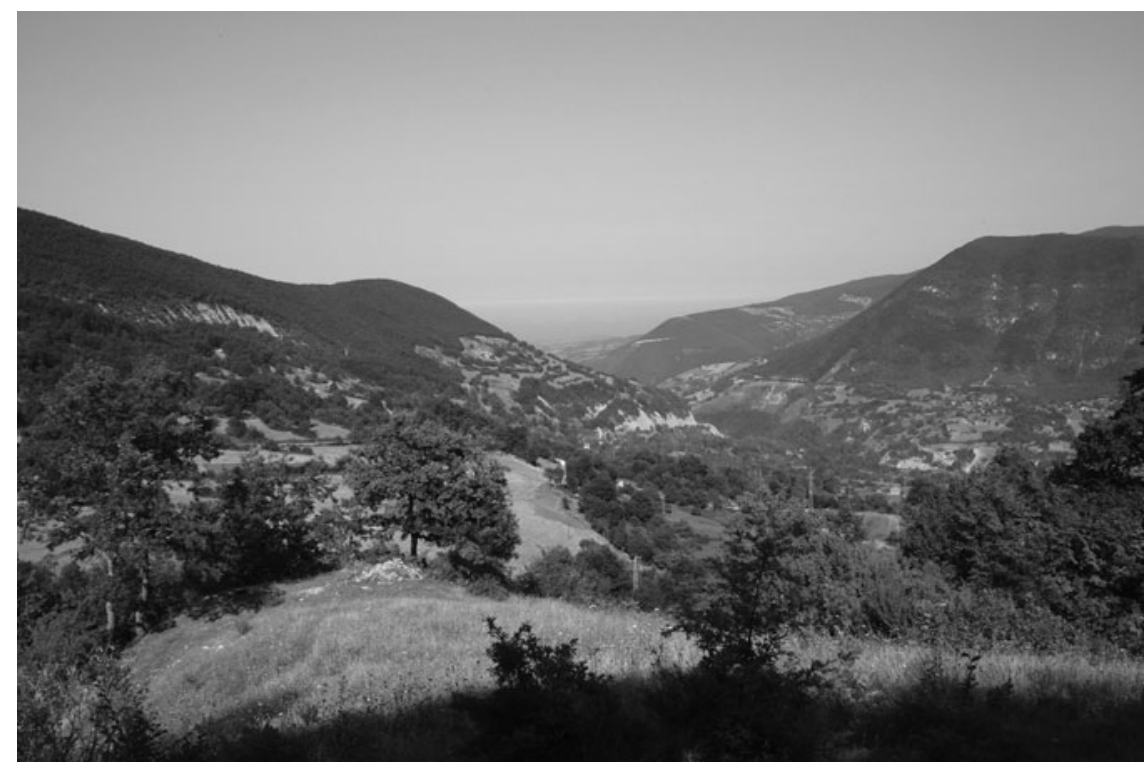

Figure 5. View from Tingirtepe looking north-west (along the Kirkgeçitcay valley towards the sea).

angular shell or fossilized limestone and establish whether this settlement and chaff. Planned luminescence analyses of others in this valley have a long history or assemblages from this site may help to conservative ceramic traditions.

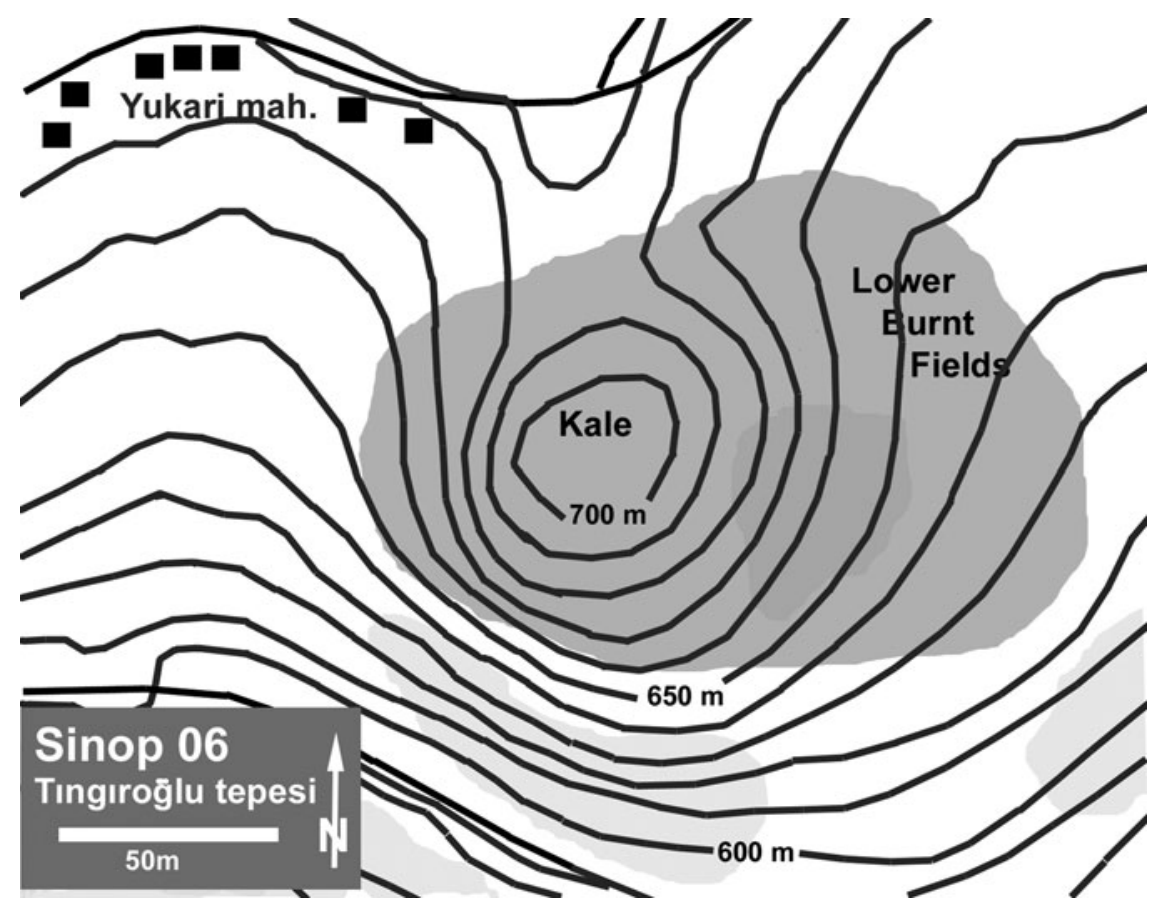

Figure 6. Outline plan of the settlement at Tingirtepe. 

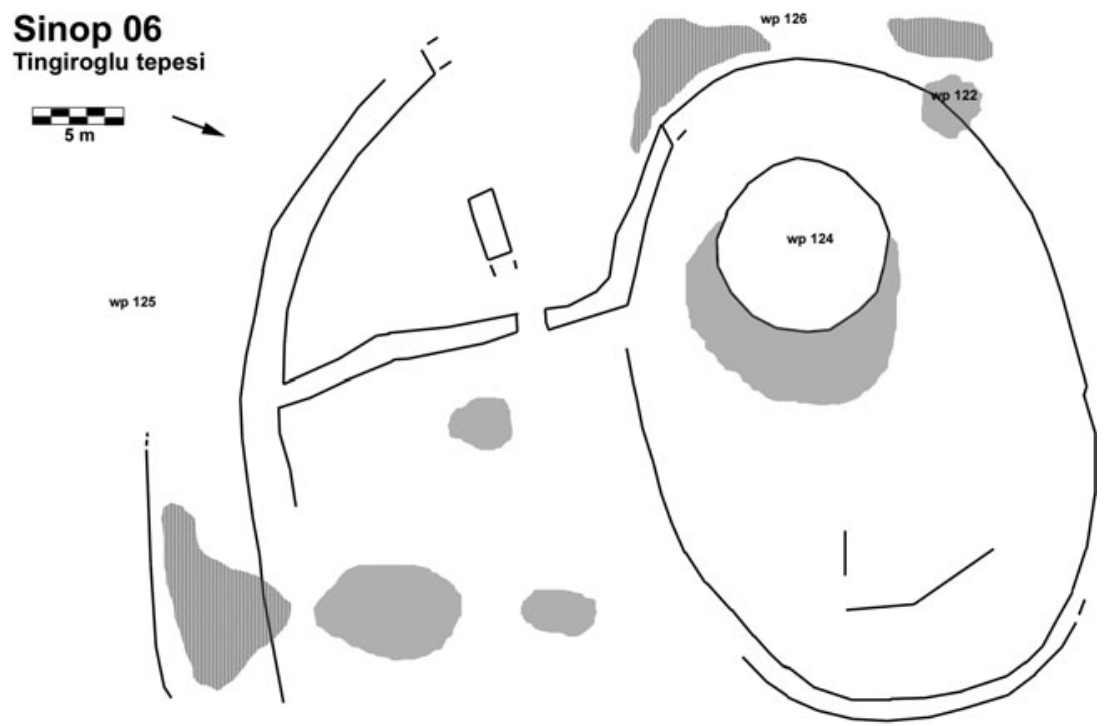

Figure 7. Plan of the upper terrace at Tingirtepe.

Iron Age settlements are relatively with the pattern observed by Xenophon common in the highlands and foothills of when he travelled along the eastern the Kırkgeçit cayı valley and may fit in portion of this coast in 400 BCE. Several

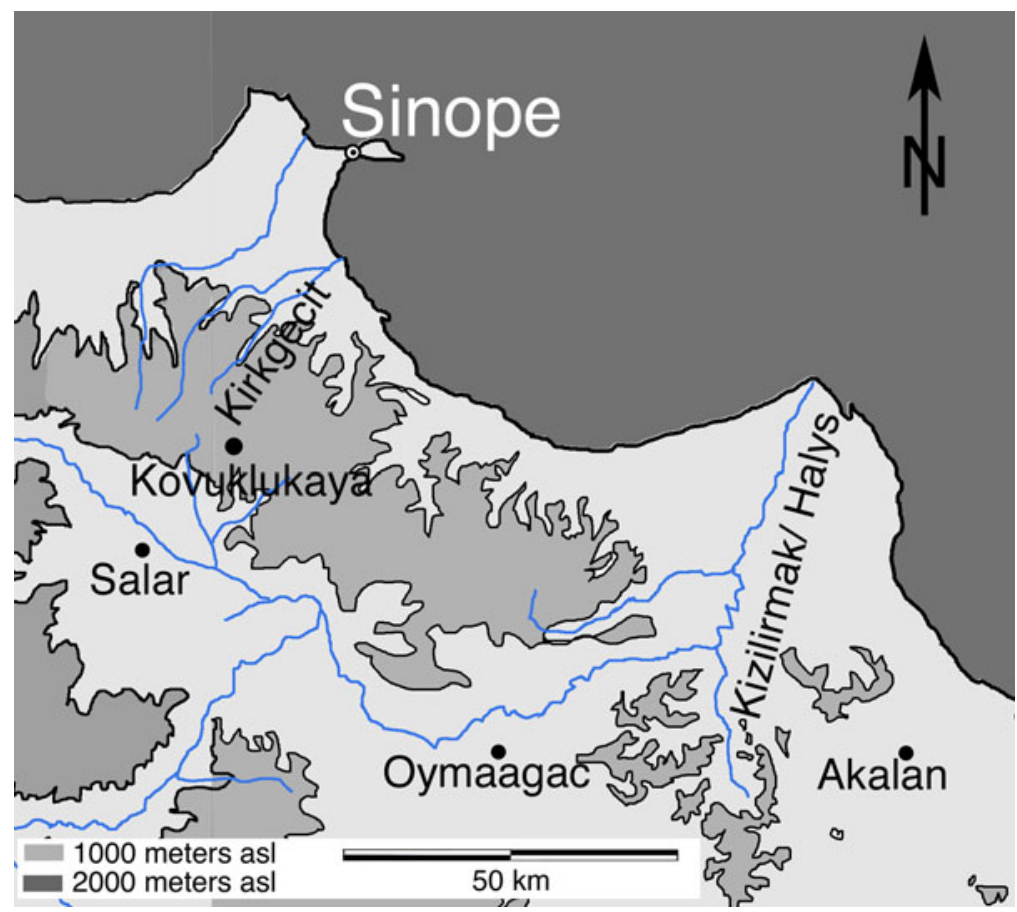

Figure 8. Iron Age sites in the Pontic mountains of central Turkey mentioned in the text. 
examples of small- to medium-sized ( $c$. $0.25-1 \mathrm{ha}$ ) settlements were recorded on the terraces overlooking the river from the north at Erikli (L12-19 and L12-20), and the south at Yakadibi (L12-23 and L1226) and Kabanlar (L12-31). Loci L12-19 and L12-20 are two scatters associated with a single small (c. $0.25 \mathrm{ha}$ ) settlement set on the southern and eastern slopes of a small mound set atop the ridge. Handmade indigenous ceramics and daub predominate at L12-19 while Hellenistic ceramics and tile were recorded at L12-20. Recall that Xenophon (see above) noted that the Drilae (near Trabzon) had numerous smaller settlements in the foothills starting not far from the coast that they would abandon and burn in the face of a strong enemy; note also that Isin (1998) remarked that nearly every Iron Age settlement recorded in the Sinop Museum survey showed some evidence of burning. The Drilae then made a stand at their stronghold in the highlands where the terrain was difficult and their enemies hemmed in and disoriented. A little further west, the Mossynoecians had settlements along the river valleys close enough for them to communicate by calling out. The series of smaller Iron Age settlements along both banks of the Kurkgeçit çayı, starting quite possibly as near to the coast as Altınoğlu (L11-09), bears a striking resemblance to these general descriptions.

Locus L12-23, a small ( $<0.1 \mathrm{ha})$ scatter of handmade indigenous ceramics and daub about $400 \mathrm{~m}$ north-east of L12-26, may have marked the location of a related contemporary installation (isolated house?), although visibility was too poor to define the extent of this scatter. About a kilometre north-east and set at a higher elevation, Locus L12-31 is a dense scatter (at least $0.5 \mathrm{ha}$ ) of handmade Hellenistic and Roman ceramics, one of the richest and most diverse assemblages of these periods that our survey has documented in the Sinop hinterland. In this valley only the large coastal site at Çakıroğlu has an assemblage as varied as that. Unfortunately there was insufficient visibility to determine the extent of Locus L12-31 beyond the area documented in the tract.

Loci L12-23 and L12-26 overlook the Kurkgeçit çayı from steep-sloping sites only $30-50 \mathrm{~m}$ above and some $200 \mathrm{~m}$ away from the river channel, while L1219, L12-20, and L12-31 are set on terraces more than $150 \mathrm{~m}$ above the river channel and a kilometre or more from it. These loci appear to be part of a system of settlements running along the Kurkgeçitçay valley from a cluster of larger villages around Tingiroğlu (see the discussion of the highlands above, particularly Loci L11-32, L11-33, and L11-34) down to the coast at Iyan'in Yeri-Altınoğlu (see Loci L11-09 andL11-10 discussed below). This line of settlements may well suggest that this valley was a mid-first millennium BCE communications route running either from the coast to highland centres or continuing all the way through the mountains, since it represents the densest concentration of indigenous settlements documented to date in the Sinop region (see Doonan, 2004a). For the most part these settlements show continuity into the second half of the first millennium BCE in that they often yield fourth-century $\mathrm{BCE}$ Greek-related ceramics; it would appear that the local Iron Age communities were conducting trade with Greeks on the coast or with the port of Sinope.

\section{Coastal plains, Ilyan'in yeri}

At Ilyan'in yeri in the district of Altınoğlu the survey documented two adjacent loci (L11-09 and L11-10) marked by a dense concentration of indigenous handmade and Hellenistic ceramics including amphora fragments and covers (Doonan et al., 2015). The Hellenistic and 
indigenous assemblages appear to form distinct clusters. The extent of the settled area was difficult to define because the site was partly overgrown, but it comprises at least 1 ha.

There are several coastal sites around the Sinop promontory that appear to show a pattern similar to that at Ilyan'in yeri. Examples have been documented on the west coast (Yama tepe, L96-65), the coast of the Karasu delta (Bostancili, L99-01; see Doonan et al., 2001), and the coast of the Demirci valley midway between Sinope and the Kurkgeçit çayı outlet (Keçioğlu, L97-114 to L97-118; see Doonan, 2004a). Each of these loci is a coastal settlement of modest size (c. $1 \mathrm{ha}$ ), set back $200-500 \mathrm{~m}$ from the coast in a location that overlooks a valley with a coastal beach landing. Recall that the Mossynoecians (see above) supplied 300 $\log$ canoes (each held 3 men) to assist the passing Greeks. A beach would provide a perfectly good landing for such boats, and the great number of boats implies that they engaged in coastal maritime activities, almost certainly fishing. This observation certainly corresponds to the pattern observed at Ilyan'ın yeri and similar sites in Sinop. Recall also that the Greeks discovered stores of salted dolphin meat and vessels filled with dolphin blubber in the mountains. Local fishing communities like the Tibarenians to the east would have undoubtedly encountered Sinopean colonists and there would have been many opportunities to help, fight, raid, and trade. Relations between these communities were critical for the maintenance of the colonial trade network that was essential to the economy of Sinope.

Black-slipped wares and amphora fragments, some stamped, attest to contact with the colonial port. The forms and fabrics of amphora finds conform to the group produced at kiln sites on the headland of Boztepe (Garlan \& Tatlican,
1998). Although the contents of the amphorae are not always clear, stamped amphorae are typically associated with wine trade. Finds of black-slipped pottery are rare in the Sinop hinterland and early amphorae only slightly more common. Their association in these coastal sites suggests that the consumption of wine may have played an important role in the entanglement of colonial and indigenous communities, paralleled in colonial encounters around the world (Dietler, 2006).

\section{Towards a Working Model of Iron Age Settlement on the Sinop Promontory}

Clearly the history of the Iron Age in Sinop is more complex than the current models would suggest. Many of the features described by Xenophon appear to have been shared by indigenous communities on the Sinop promontory (see Table 1). The Kırkgeçit cayı valley appears to show some evidence of economic integration from coast to highland (no. 1 on Table 1) beginning at the latest in the fourth century BCE, based on finds of imported ceramics, while the more important centres like Tingiroğlu and Salar were clearly located at higher elevations or over the mountains (no. 2). Small settlements appear to have been strung along the banks of the river (no. 5), at distances that are consistent with Xenophon's observation that locals would call from one settlement to the next (no. 4). Many settlements show evidence of burning (no. 6 ), and survey finds at Tingirtepe are consistent with the mention of ramparts, palisades, and towers (no. 8). It is intriguing to consider the possibility that sites like Ilyan'in yeri were home to agricultural settlers who took advantage of the seasonal or occasional opportunities offered by their proximity to the sea (no. 3). Being located 
near the coast, they may have provided an arena for informal markets and fishing similar to the economy of the Tibarenians reported by Xenophon. It is clear that fishing was an important activity at Sinop kale that attracted visitors from around the Black Sea.

Two patterns have begun to emerge in the Iron Age settlement of the Sinop promontory. The first, most probably dating from the end of the second-early first millennia $\mathrm{BCE}$ and continuing into the Hellenistic period, consists of dispersed networks of settlements, some quite large (5-6 ha), in the foothills and highlands overlooking river-based communication routes. We are using the broad term Iron Age to refer to these horizons as well as to the assemblages that coincide with Archaic and Classical Greek horizons. The upland settlements are clearly larger, and the sea appears to have attracted only marginal (possibly seasonal) interest. The more important population centres may well have looked south towards central Anatolia and the north Anatolian rift valley. The second pattern, dating from the mid to late first millennium BCE (Late Iron Age), is seen in the engagement of indigenous and local communities through exchange with outsiders at near-coastal sites and continues via pre-existing indigenous networks up into the mountain communities.

The Iron Age occupation of the Sinop promontory can be sketched in several stages:

- Stage 1 (second-early first millennium $\mathrm{BCE})$ : continuation of dominant Bronze Age patterns: low density subsistence based on terrestrial agriculture and seasonal exploitation of maritime resources; possible symbiotic relationship between mobile fishing communities and more sedentary terrestrial counterparts; organization of communities along river valleys;
- Stage 2 (ninth-seventh century BCE): quickening of maritime activity at Sinope by outsiders bearing ceramics from the northwest and the east (Doonan 2007a; Doonan et al. 2016);

- Stage 3 (seventh-fifth century $\mathrm{BCE}$ ): Ionian Greek colonization at Sinope followed by establishment of colonies that controlled access to the east coast of the Black Sea; limited economic connections between Sinope and the immediate hinterland; emergence of larger indigenous centres, some fortified; intensification of colonial long-distance trade (Akurgal, 1956; Doonan et al., 2016);

- Stage 4: (fourth-first century BCE): expansion of viticulture on the slopes above the colony (on Boztepe) and agricultural and natural resources in the hinterland initial exchange may have included wine from Sinope for timber and other hinterland resources (Doonan, 2015); establishment of transport routes leading inland from the coast; expansion of indigenous centres in the highlands (Doonan, 2003).

Considering the emerging picture of the Anatolian Pontic coast in light of contemporary examples of colonial-indigenous relations in other regions yields some important contrasts and parallels. Dietler's analysis of colonial-indigenous relations in Massalia (Marseille) and the western Mediterranean highlights the importance of indigenous agency in the entanglement of communities (Dietler, 1997, 2010; Dietler and López-Ruiz, 2009). He has highlighted the central importance of wine as a commodity produced by colonial communities in response to strong indigenous demand, and the adaptation of the rituals and material accoutrements of social drinking by indigenous communities. Dietler (1997, 2010) notes intensified vineyard production on the slopes adjacent 
to Massalia in the third century $\mathrm{BCE}$, a pattern that is similar to the expansion of apparently prosperous farmsteads and wine amphora production on the defensible headland of Boztepe just above Sinope in the fourth century (Doonan et al., 2015). This coincides with the appearance of amphorae and black-slipped fine wares in the hinterland, suggesting that wine production at Sinope was specifically connected to the intensification of trade relations with its hinterland.

Another significant parallel between the Anatolian Black Sea coast and the western Mediterranean can be seen in the spread of defensive architecture among local groups following entanglement with colonial communities (Dietler, 1997, 2010). The military build-up is by no means merely a response to the presence of colonists, but likely to reflect the intensification of local rivalries (recall the rivalries in Xenophon's descriptions of the Mossynoecians and the defensibility of their strongholds and those of the Drilae). Archaeological sites like Akalan, Salar, and Tingirtepe broadly correspond to these descriptions. Clearly Xenophon's narrative indicates warlike rivalries between indigenous groups; in contrast, this does not appear to be a feature of earlier periods. In Pontic Anatolia this is most likely to be related to economic and political processes linked not only to Greek colonization along the coast, but to relations with Persia that eventually gave rise to the Pontic dynasties.

Equally important are the contrasts: the colonial impact on communities along the Anatolian Black Sea coast never reached the scale seen along the extensive river systems of the northern Black Sea or the Rhône valley. Imported colonial wares can be traced in considerable numbers far up these valleys from the mid-sixth century BCE. Forest-steppe settlements in Ukraine, like Belskoye Gorodische, yield large quantities of imported Greek amphorae from the sixth century onward (Tsetskhladze, 1998). Imports from Massalia, soon followed by local production of pseudo-Ionian and grey pseudo-Phokaian wares, extend well into the Rhône valley (Dietler, 1997). The grey wares have many forms derived from local as well as imported forms; vessels related to drinking dominate among import-inspired types. Not only do these examples demonstrate colonial engagement at a much earlier date than in the Sinop area, but they also show economic activity at a much greater scale.

In closing, it is hoped that these interpretations, based, as they are, on the reading of a specific historical source, can nonetheless form the basis for a discussion about Iron Age settlement along the Anatolian coast of the Black Sea. The Sinop Regional Archaeological Project continues to expand the site-by-site analysis of ceramics within an interpretive framework that allows us to consider the organization of the economies and social order of indigenous communities. It is also hoped that this discussion can reorient some interest in this region away from the identification of historically attested ethnic groups toward an interest in the geography of early Black Sea communities and the role the organization of those communities played in their engagement with Ionian colonists and the growing Black Sea economy of the first millennium BCE.

\section{ACKNOWLEDGEMENTs}

The work described here was carried out by the members of the Sinop Regional Archaeological Project from 1996 to 2012 and between 2015 and 2017 with permission from the Turkish Ministry of Culture and Tourism, to whom I extend my thanks. I acknowledge the members of our field teams, too numerous to list here, and our Turkish government representatives 
for their contributions to the results summarised here. Furthermore, I would like to thank the staff of the Sinop Museum, in particular former Directors M.A. Işin, I. Tatlican, F. Dereli, and current Director H. Vural for advice and assistance over many years. Members of the Sinop community, particularly C. Kaya, H. Onur, and Culture Director $\mathrm{H}$. Tosun have helped us in many ways over these years. Thanks are expressed to E.S. Sherratt and A. Bauer who made comments on this article while it was being developed. Ceramic studies by K. Domzalski and A. Smokotina have greatly helped identify key Greek and Roman wares. The initial draft of this article was written during the tenure of a Residential Fellowship at the Getty Villa (Spring 2014). Many thanks are due to the Getty Research Institute and my colleagues in the highly stimulating 'Connecting Seas' research group.

\section{REFERENCES}

Akurgal, E. 1956. Sinop Kazıları / Die Ausgrabungen von Sinope. Türk Arkeoloji Dergesi, VI.1 6: 47-61.

Bauer, A.A. 2006. Fluid Communities: Interaction and Emergence in the Bronze Age Black Sea (January 1, 2006). Dissertation available at: <https://repository.upenn.edu/dissertations/

AAI3211036> Accessed 15 December 2017.

Bauer, A.A. \& Sherratt, E.S. 2018. The Handmade, Pre-Colonial Ceramics from the Citadel of Sinop, Turkey: Some Preliminary Observations. Paper presented at the Archaeological Institute of America Annual Meetings, Boston (MA), 4-7 January 2018.

Casson, A. 2014. Black Sea Change: A Revision of the Sinop Ceramic Chronology Using Luminescence Dating. Unpublished $\mathrm{PhD}$ dissertation, University of Washington.

Casson, A., Bauer, A. \& Doonan, O. 2012. Constructing Prehistory in a Survey
Context: Microscopy and Luminescence of Ceramics from Sinop, Turkey. Unpublished paper presented at the Society for American Archaeology Annual Meetings, Memphis (TN), April 2012.

Caukwell, G. 1972. Introduction. In Xenophon: The Persian Expedition (R. Warner trans.). Harmondsworth: Penguin, pp. 9-48.

Czichon, R.M., Klinger, J., Breuer, P., Eerbeek, J., Fox, S., Marinova-Wolff, E. et al. 2011. Archäologische Forschungen am Oymaagac Höyük/Nerik(?) in den Jahren 2007-2010. Mitteilungen der Deutschen Orient Gesellschaft, 143: 169-250.

Dietler, M. 1997. The Iron Age in Mediterranean France: Colonial Encounters, Entanglements, and Transformations. Journal of World Prehistory, 11: 269-357.

Dietler, M. 2006. Alcohol: Anthropological/ Archaeological Perspectives. Annual Review of Anthropology, 35: 229-49.

Dietler, Michael, and Carolina López-Ruiz. 2009. Colonial encounters in ancient Iberia: a coda. In: M. Dietler and C. López-Ruiz, eds. Colonial Encounters in Ancient Iberia: Phoenician, Greek, and Indigenous Relations, Chicago: University of Chicago Press, pp. 299-312.

Dietler, M. 2010. Archaeologies of Colonialism: Consumption, Entanglement, and Violence in Ancient Mediterranean France. Berkeley (CA): University of California Press.

Dönmez, Ş. 2004. Boyabat-Kovuklukaya: A Bronze Age Settlement in Sinop Province. Ancient Near Eastern Studies, 41: 38-84.

Dönmez, Ş. 2007. Sinop Province during the Iron Age in Light of New Research. Anatolia Antiqua, 15: 59-65.

Dönmez, Ş. 2008. An Overview of the 2nd Millennium bc Cultures of the Central Black Sea Region in the Light of New Research. TÜBA-AR, 11: 85-104.

Dönmez, S. 2011. New Evidences on the Existence of Eurasian Horse-Riding Nomads in the Black Sea Region, Turkey. In: A. Öztan and S. Dönmez, eds. Karadeniz'den Frat'a Bilgi Üretimleri: Önder Bilgi'ye Armağan Yazılarl From the Black Sea to the Euphrates Knowledge Production: Studies in Honor of Önder Bilgi. Istanbul. Bilgin Kültür Sanat Yayınları, pp. 135-46.

Dönmez, Ş. \& Beyazit, A. 2008. A General Look at the Central Black Sea Region of Turkey during the Middle Bronze Age 
and a New Approach to the Zalpa Problem in the Light of New Evidence. In: J.G. Dercksen, ed. Anatolia and the Jazira during the Old Assyrian Period. Leiden: Netherlands Institute for the Near East, pp. 101-35.

Dönmez, Ş. \& Ulugergerli, E. 2010. Akalan Arkeojeofizik Araştırmaları. Anadolu Araştırmaları, 19: 13-40.

Doonan, O. 2003. Production in a Pontic Landscape: The Hinterland of Greek and Roman Sinope. In: M. Faudot, A. Fraysse and E. Geny, eds. Pont-Euxin et commerce: la genèse de la route de soie. Besançon: Presses Universitaires Franc-Comtoises, pp. 185-98.

Doonan, O. 2004a. Sinop Landscapes: Exploring Connection in the Hinterland of a Black Sea Port. Philadelphia: University of Pennsylvania Museum Press.

Doonan, O. 2004b. Sampling Sinop: Archaeological Survey in a Low Visibility Environment. In: L. Wandsnider \& E. Athanassopoulou, eds. Recent Developments in Mediterranean Survey Archaeology. Philadelphia: University of Pennsylvania Museum Press, pp. 37-54.

Doonan, O. 2007a. Colony and Conjuncture: The Early Greek Colony at Sinope. In: J. Cobet et al., eds. Frühes Ionien: Eine Bestandaufsnahme. Berlin: Deutsches Archäologisches Institut, pp. 613-20.

Doonan, O. 2007b. New Evidence for the Emergence of a Maritime Black Sea Economy. In: V. Yanko-Hombach, A. Gilbert, N. Panin \& P. Dolukhanov, eds. The Black Sea Flood Question: Changes in Coastline, Climate and Human Settlement. Dordrecht: Springer, pp. 697-710.

Doonan, O. 2015. Tumuli and the Creation of a Middle Ground in the Hinterland of Greek Sinope. In: O. Henry \& U. Kelp, eds. Tumulus as Sema: Proceedings of an International Conference on Space, Politics, Culture and Religion in the First Millennium $B C$. Berlin: DeGruyter, pp. 657-65.

Doonan, O. \& A. Bauer 2005. Sinop Province Archaeological Project: Report on the 2003 Field Season. Arastırma Sonuçlar Toplantısı, 22: 275-84.

Doonan, O., Gantos, A., Hiebert, F., Besonen, M. \& Yaycioğlu, A. 2001. Systematic Survey of the Karasu River Valley (Sinop Province), 1998-99. TÜBA$A R, 4: 113-35$.
Doonan, O., Casson, A. \& Gantos, A. 2008. Sinop Province Archaeological Project: Report on the 2006 Field Season. Arastirma Sonuçlar Toplantısi, 25: 133-150.

Doonan, O., Bauer, A., Casson, A., Conrad, M., Besonen, M., Evren, E. \& Domzalski, K. 2015. Sinop Regional Archaeological Project: Report on the 2010-2012 Field Seasons. In: S. Steadman \& G. McMahon, eds. The Archaeology of Anatolia: Current Work. Newcastle: Cambridge Scholars Press, pp. 298-327.

Doonan, O., Vural, H., Goldman, A., Bauer, A., Sherratt, E.S., Rempel, J., et al., A. 2016. Sinope Ancient Kale Excavations, Preliminary Report on Season 1. Antiquity Project Gallery. Available online at http://antiquity.ac.uk/ projgall/578. Accessed 15 December 2017.

Doonan, O., Vural, H., Goldman, A., Bauer, A., Rempel, J., Sherratt, E.S., et al. 2017. Sinop Kale Excavations: The 2015-16 Report. In: S. Steadman \& G. McMahon, eds. Archaeology of Anatolia Vol. 2. Newcastle: Cambridge Scholars Press, pp. 178-99.

Flower, M.A. 2012. Xenophon's Anabasis or the Expedition of Cyrus. Oxford: Oxford University Press.

Garlan, Y. \& Tatlican, İ. 1998. Fouilles d'ateliers amphoriques a Nisiköy et a Zeytinlik (Sinop) en 1996 et 1997. Anatolia Antiqua, 6: 407-22.

Gavriljuk, N. 2005. Fishery in the Life of the Nomadic Population of the Northern Black Sea Area in the Early Iron Age. In: T. Bekker-Nielsen, ed. Ancient Fishing and Fish Processing in the Black Sea Region. Aarhus: Aarhus University Press, pp. 105-13.

Genz, H. 2004. Büyükkaya I: Die Keramik der Eisenzeit. Mainz: Philipp von Zabern.

Genz, H. 2011. The Iron Age in Anatolia. In: G. Tsetskhladze, ed. The Black Sea, Greece, Anatolia and in the First Millennium B.C. Leuven: Peeters, pp. 331-68.

Isin, M.A. 1998. Sinop Region Field Survey. Anatolia Antiqua, 6: 95-139.

Kramer, C. 1977. Pots and Peoples. In: L.D. Levine \& T. Culyer Young, eds. Mountains and Lowlands: Essays in the Archaeology of Greater Mesopotamia. Malibu (CA): Undena, pp. 91-112.

Lipka, M. 1995. Anmerkungen zu geographischen, wirtschaftlichen und sozialen Verhältnissen zur südöstlichen Schwartzmeerküste Ende des fünften/ 
Anfangs viertel Jhs. v. Chr. Klio, 77: 65-73.

Macridy-Bey, T. 1907. Une citadelle archaïque du Pont. Mitteilungen der Vorderasiatischen Gesellschaft, 4: 1-9.

Rood, T. 2014. Space and Landscape in Xenophon's Anabasis. In: K. Gilhuly \& N. Worman, eds. Space, Place, and Landscape in Ancient Greek Literature and Culture. Cambridge: Cambridge University Press, pp. 63-93.

Steadman, S. \& McMahon, R.G. eds. 2011. The Oxford Handbook of Ancient Anatolia, 10000-323 B.C.E. Oxford: Oxford University Press.

Stylianou, P. 2004. One Anabasis or Two? In: R. Lane Fox, ed. The Long March: Xenophon and the Ten Thousand. New Haven \& London: Yale University Press, pp. 68-96.

Tsetskhladze, G.R. 1998. Greek Colonisation of the Black Sea Area. In: G.R. Tsetskhladze, ed. The Greek Colonisation of the Black Sea Area: Historical Interpretation of Archaeology. Stuttgart: Franz Steiner, pp. 9-68.

Tsetskhladze, G.R. 2012. The Southern Black Sea Coast and its Hinterland: An Ethno-Cultural Perspective. In: G.R. Tsetskhladze, ed. The Black Sea, Paphlagonia, Pontus and Phrygia in Antiquity: Aspects of Archaeology and Ancient History (BAR International Series 2432). Oxford: Archaeopress, pp. 235-41.

Tsetskhladze, G.R. 2014. Black Sea Ethnicities. In: J. McInerney, ed. $A$ Companion to Ethnicity in the Ancient Mediterranean. Chichester: WileyBlackwell, pp. 312-26.
Weimert 1984. Wirtschaft als Landschaftsgebundenes Phänomen. Die antike Landschaft Pontos. Frankfurt: Lang.

Yilmaz, M.A. 2012. Contributions to the Early Iron Age Problem in the Central Black Sea Region in Light of Vezirköprü / Oymaağaç Höyük Ceramic. TÜBA-AR, 15: 69-78.

\section{Biographical Note}

Owen Doonan has been teaching at California State University Northridge since 2003, following a decade of teaching and research at Bilkent University (Ankara, Turkey), the University of Illinois-Chicago and the University of Pennsylvania. He has devoted the past 25 years to research and teaching about the ancient cultures of the Mediterranean, the Black Sea and the Middle East. He cofounded the Sinop Regional Archaeological Project in 1996 and has served as its Director ever since.

Address: Owen Doonan, Program in Art History, Department of Art, California State University Northridge, 18111 Nordhoff St., Northridge, CA 913308300, USA. [email: owen.doonan@csun. edu]

\section{Xénophon et le paysage de la Mer Noire: modèles d'implantation de l'habitat à l'âge du Fer sur la péninsule de Sinope (Turquie)}

Les études concernant l'âge du Fer en Anatolie ont rarement prêté suffisamment d'attention aux habitats et à l'organisation sociale de l'espace habité. L'Anabase de Xénophon contient le récit du périple d'un Grec en Anatolie orientale et le long de la côte de la Mer Noire en 400 av. J.-C., donc relativement tôt dans le processus de colonisation de cette région. On utilisera ses observations pour établir un modèle de base concernant l'habitat dans la zone côtière de la Mer Noire en Anatolie, que l'on comparera ensuite avec les résultats de prospections archéologiques récentes et de projets de recherche connexes sur la péninsule de Sinope. On proposera un modèle plus fourni des habitats de l'âge du Fer et des rapports entre colons et indigènes dans cette région, compte tenu des études récentes sur le phénomène de colonisation en Méditerranée occidentale et dans les régions septentrionales de la mer Noire. Translation by Madeleine Hummler

Mots-clés: âge du Fer en Anatolie, colonisation grecque, âge du Fer en Mer Noire, Xénophon 


\section{Xenophon im Schwarzmeergebiet: eisenzeitliche Besiedlungsmodelle auf der Halbinsel von Sinop (Türkei)}

Die Siedlungsstruktur und die räumliche Organisation der Gesellschaft haben oft ungenügend Beachtung in der Forschung der Eisenzeit in Anatolien gefunden. Xenophons Anabasis enthält die Beobachtungen eines griechischen Außenseiters, der um 400 v. Chr. in Ostanatolien und entlang der Küste des Schwarzen Meeres reiste, also relativ früh in der Kolonisierung der Gegend. Seine Beobachtungen dienen bier zum Aufbau eines Grundmodells der Besiedlung an der anatolischen Schwarzmeerküste, das dann mit den Ergebnissen von neueren archäologischen Prospektionen und damit verbundenen Forschungen auf der Halbinsel von Sinop verglichen wird. Es ergibt sich eine reichere Modellierung der einheimischen eisenzeitlichen Siedlungen und der Beziehungen zwischen Kolonisten und Kolonisierten in dieser Gegend, die man mit neueren Forschungen im westlichen Mittelmeerraum und in den nördlichen Schwarzmeerbereichen vergleichen kann. Translation by Madeleine Hummler

Stichworte: Eisenzeit in Anatolien, griechische Kolonisierung, Eisenzeit im Schwarzmeergebiet, Xenophon, Landschaftsarchäologie 